\title{
Interruption in the work of nursing professionals: conceptual analysis
}

\author{
Interrupção no trabalho de profissionais de enfermagem: análise conceitual \\ Interrupción en el trabajo de profesionales de enfermería: análisis conceptual
}

Weslen Carlos Junior de Freitas' ORCID: 0000-0003-3614-7701

Aline Carrilho Menezes'

ORCID: 0000-0001-7658-4039

Luciana Regina Ferreira da Mata" ORCID: 0000-0002-5080-4643

Ana Luisa Brandão de Carvalho Lira"' ORCID: 0000-0002-7255-960X

Letícia Helena Januário' ORCID: 0000-0002-8535-8292

Helen Cristiny Teodoro Couto Ribeiro ORCID: 0000-0001-9365-7228

'Universidade Federal de São João del Rei. Divinópolis, Minas Gerais, Brazil.

"Universidade Federal de Minas Gerais. Belo Horizonte, Minas Gerais, Brazil.

I'Universidade Federal do Rio Grande do Norte. Natal, Rio Grande do Norte, Brazil.

How to cite this article:

Freitas WCJ, Menezes AC, Mata LRF, Lira ALBC, Januário LH, Ribeiro HCTC. Interruption in the work of nursing professionals: conceptual analysis.

Rev Bras Enferm. 2022;75(2):e20201392. https://doi.org/10.1590/0034-7167-2020-1392

Corresponding author: Weslen Carlos Junior de Freitas E-mail: weslen@live.com

EDITOR IN CHIEF: Dulce Barbosa ASSOCIATE EDITOR: Alexandre Balsanelli

Submission: 12-31-2020

Approval: 05-18-2021

\section{ABSTRACT}

Objectives: to analyze the concept of "interruption in the work of nursing professionals". Methods: conceptual study according to the method proposed by Walker and Avant through integrative literature review. The study searched the databases using the descriptors: "Attention", "Attention Bias", "Health Personnel","Nurses", “Patient Safety" and"Medical Malpractices". The sample consisted of 36 studies. Results: the antecedents were alarms, answering phone calls, providing patient care, and lack of material/medicine. The defining attributes were pause, suspension, breakage, and intrusion. In relation to the consequences, the study highlighted the increase in frequency and severity of medication errors and change of focus. Final Considerations: the conceptual analysis identified the attributes, antecedents, and consequences and allowed to build an operational definition for "interruption in the work of nursing professionals". It will contribute to the improvement of the work process and the creation of strategies that ensure safer care for the patient.

Descriptors: Nursing; Patient Safety; Nursing Care; Concept Formation; Work.

\section{RESUMO}

Objetivos: analisar o conceito "interrupção no trabalho de profissionais de enfermagem" Métodos: estudo conceitual conforme método proposto por Walker e Avant conduzido mediante revisão integrativa da literatura. A busca nas bases de dados foi realizada mediante os descritores:" Attention", "Attention Bias", "Health Personnel", "Nurses", "Patient Safety" e "Medical Errors". A amostra foi composta por 36 estudos. Resultados: os antecedentes do conceito identificados foram: alarmes, atender chamadas telefônicas, prestar assistência ao paciente e falta de material/medicamento. Os atributos definidores foram: pausa, suspensão, quebra e intrusão. Consequentes destacados: aumento na frequência e gravidade dos erros de medicação; e mudança de foco. Considerações Finais: a análise conceitual identificou os atributos, antecedentes e consequentes e permitiu construir uma definição operacional para "interrupção no trabalho de profissionais de enfermagem". Isso contribuirá na melhoria do processo de trabalho e na criação de estratégias que garantam uma assistência mais segura ao paciente. Descritores: Enfermagem; Segurança do Paciente; Cuidados de Enfermagem; Formação de Conceito; Trabalho.

\section{RESUMEN}

Objetivos: analizar el concepto "interrupción en el trabajo de profesionales de enfermería". Métodos: estudio conceptual conforme método propuesto por Walker y Avant conducido mediante revisión integrativa de la literatura. Búsqueda en las bases de datos realizada mediante los descriptores: "Attention", "Attention Bias", "Health Personnel", "Nurses", "Patient Safety" $y$ "Medical Errors". Muestra composta por 36 estudios. Resultados: los antecedentes del concepto identificados fueron: alarmes, atender llamadas telefónicas, prestar asistencia al paciente y falta de material/medicamento. Los atributos definidores fueron: pausa, suspensión, quiebra e intrusión. Consecuentes destacados: aumento en la frecuencia y gravedad de los errores de medicación; y cambio de enfoque. Consideraciones Finales: el análisis conceptual identificó los atributos, antecedentes y consecuentes y permitió construir una definición operacional para "interrupción en el trabajo de profesionales de enfermería". Eso contribuirá en la mejoría del proceso de trabajo y en la creación de estrategias que garantizan una asistencia más segura al paciente.

Descriptores: Enfermería; Seguridad del Paciente; Atención de Enfermería; Formación de Concepto; Trabajo. 


\section{INTRODUCTION}

Interruptions during health care activities can lead to risks for both patients and the professionals involved. Interruptions in the workflow for reasons not related to the task are significantly associated with the increased stress of the professionals ${ }^{(1)}$. Disruption events affect memory at work, divert focus from the main task, and, consequently, overload cognitive functions ${ }^{(2-3)}$, intensifying the risk of mistakes. Unnecessary interruptions occur with high frequency during health care ${ }^{(4)}$, and they have been explored mainly within the scope of nursing.

Nursing professionals are interrupted between 0.4 and 13.9 times per hour ${ }^{(5)}$. In the United States, a study identified an average of 85 interruptions per work shift among emergency sector nurses, with an average of 8,7 interruptions per hour. The main sources of interruptions started by other nursing professionals (40\%), other professionals of the multidisciplinary team (15.6\%), telephone calls (12\%), medical professionals (9\%), and unexpected patient care $(5.2 \%)^{(3)}$. In China, a study noted that there were interruptions in $94,5 \%$ of the preparation activities of 180 doses of drugs administered. In this case, the sources were related to the workplace (32.4\%), caregivers (24.5\%), medical professionals $(10.8 \%)$, other nursing professionals $(9.5 \%)$, and communication problems $(8.7 \%)^{(6)}$.

In Brazil, an observational study showed that interruptions during drug preparation and administration activities occurred in $44.0 \%$ of the observations. The main reasons for interruption were parallel conversation (46.8\%), overlapping tasks $(8.2 \%)$, instruction from other professionals (7.2\%), lack of material $(7.2 \%)$, noise in the workplace $(4.5 \%)^{(7)}$. Interruptions are not always associated with adverse events since in some cases, they may be necessary. For example, pausing to change or adjust a defective multiparameter monitor during a surgical procedure is essential for patient safety ${ }^{(8)}$. However, studies indicate that nursing professionals are more likely to make mistakes when they are interrupted $^{(6,9)}$, for example, medication errors (ME), such as wrong dose, wrong patient and missed dose ${ }^{(2)}$, wrong schedule, lack of records of medications administered, failure to doublecheck and failure to comply with infection control measures ${ }^{(10)}$.

On the other hand, the literature shows different definitions for an interruption in the work of nursing professionals. Some are conflicting, and others have complex terms to understand and observe ${ }^{(4,11-12)}$. A study states that to be considered the "interruption of the main activity", a minimum of ten seconds is required ${ }^{(13)}$. Another study states that the occurrence of interruption does not depend on the duration. In this case, any intrusion of a secondary, unplanned, and unexpected activity leads to the discontinuity of the primary activity ${ }^{(14)}$. Some definitions make it difficult to understand the concept. For example, interrupt is "any event that disturbs the nurse in the process of administering the drug $^{\prime \prime(15)}$. There are also definitions that present interruption as a synonym for distraction, which refers to a distinct concept ${ }^{(16)}$.

The inconsistencies of the definitions in the literature and the absence of a standardized terminology of the concept of interruption in the work of nursing professionals make it difficult to understand, operationalize research and compare studies. Consequently, elaborating strategies to prevent and mitigate interruptions to promote patient safety in health services becomes more difficult.

The construction of an operational definition can contribute to the scientific production and the strengthening of nursing, as well as subsidize improvements in the nursing work process through the elaboration of strategies for prevention and mitigation of interruptions.

To that end, this study seeks to analyze the evidence that contributes to the understanding of the concept "interruption in the work of nursing professionals", with the identification of the variables of this concept, namely, attributes, antecedents, and consequences ${ }^{(17)}$.

\section{OBJECTIVES}

To analyze the concept of "interruption in the work of nursing professionals".

\section{METHODS}

\section{Ethical aspects}

The researchers extracted the data through the literature search, that is, the study did not involve the participation of human beings, so an Ethics and Research Committee exempted it from consideration.

\section{Theoretical-methodological framework and type of study}

This is a methodological study based on the conceptual analysis model proposed by Walker and Avant ${ }^{(18)}$.

The concept analysis aims to examine the structure and function to understand the phenomena of a specific area of knowledge ${ }^{(18)}$. The adopted model consists of eight steps ${ }^{(18)}$. This study developed seven of them, namely: 1) selection of the concept, 2 ) determination of the objectives or purposes of the analysis, 3) identification of uses for the concept, 4) determination of defining attributes, 5) identification of antecedents and consequences, 6 ) identification of the model case, and 7) identification of the additional case (opposite case). The study did not find empirical references (Stage 8) for interruptions in the work of nursing professionals, as this is a behavior evaluated for a short time in the context of patient safety. We should note that this study performed phases similar to the integrative literature review process. Thus, the study selected the concept with intense consideration. The chosen concept is relevant to the researcher and may contribute to the development of other studies in the area of interest ${ }^{(18)}$. The defined concept of interest was the "interruption in the work of nursing professionals", a behavior that often occurs in health services and has been the subject of studies by the research group ${ }^{(7-8)}$.

\section{Methodological procedures}

\section{Data source}

Aiming to know the characteristics correlated to the concept and develop an operational definition ${ }^{(18)}$, the study carried out an integrative literature review that followed the steps: $a$ ) identification of the research problem; b) literature research, based on well-defined search strategies; c) evaluation, stratification of the 
studies, methods used and feasibility of the data; d) data analysis, extraction and synthesis of the results found; e) presentation and completion of all the steps of the research review ${ }^{(19)}$.

Thus, the study established the following guiding question: "What are the attributes, antecedents, and consequences of work interruption events experienced by nursing professionals in health services?". It used the acronym PICO: (population, intervention, comparison, and outcomes), where: $P$ represents the studied population that is, nursing professionals; I - not applicable; $\mathrm{C}$ - not applicable; and $\mathrm{O}$ - antecedents, consequences, and essential attributes of work interruptions.

The indexed databases Latin American literature in Health Sciences (LILACS), Medical Literature Analysis and Retrieval System Online (MEDLINE, via PubMed), and Cumulative Index to Nursing and Allied Health Literature (CINAHL) listed the articles through access to the Portal of Journals of Improvement of Higher-Education Personnel (CAPES). As inclusion criteria, the study considered the complete articles available electronically in Portuguese, English, and Spanish and answered the research question. There was no limitation on the year of publication to increase the scope of the studies. The study excluded opinion articles, abstracts, theses, dissertations, and editorials.

\section{Collection and organization of data}

The study collected the data between September 2019 and January 2020 through the software State of Art through Systematic Reviews (START) ${ }^{\circ}$ version 3.0.3 Beta, for data organization and analysis. It is a free tool, developed by the research and Engineering Laboratory of Software (LAPES) of the Federal University of São Carlos.

The study used the boolean operators AND and OR to perform a search on the databases as well as the controlled and indexed descriptors in the Health Sciences descriptors (DeCS) and their respective correspondents in the Medical Subject Headings (MeSH): Attention (Atenção), "Attention bias" (Viés de Atenção), "Health personnel” (Pessoal de Saúde), "Nurses" (Enfermeiros e Enfermeiras), "Patient safety" (Segurança do Paciente) and "Medical Malpractices" (Erros Médicos).

First, researchers read the title and abstract of each article and pre-selected those that met the inclusion criteria. Subsequently, they analyzed the whole articles and selected those that converged with the guiding question and the research objective. The researchers extracted data referring to antecedents and consequences from the studies through the identification of contributing and consequential factors in the activities in progress. The research identified the attributes by terms that characterized an interruption.

The study developed a database to support the analysis of the concept of interruption in the work of nursing professionals with the extraction of the following variables: type of study, objectives, country of the study, population, sample, scenario, attributes, antecedents, and consequences. Researchers extracted empirical data from the studies by questioning the situations described in each article, such as: How was the interruption defined or characterized? What were the consequences related to the interruption?

To maintain methodological rigor, researchers conducted the search and selection processes of the articles according to the recommendations of the guide Preferred Reporting Items for Systematic Reviews and Meta Analyses (PRISMA) ${ }^{(20)}$, detailed in Figure 1.

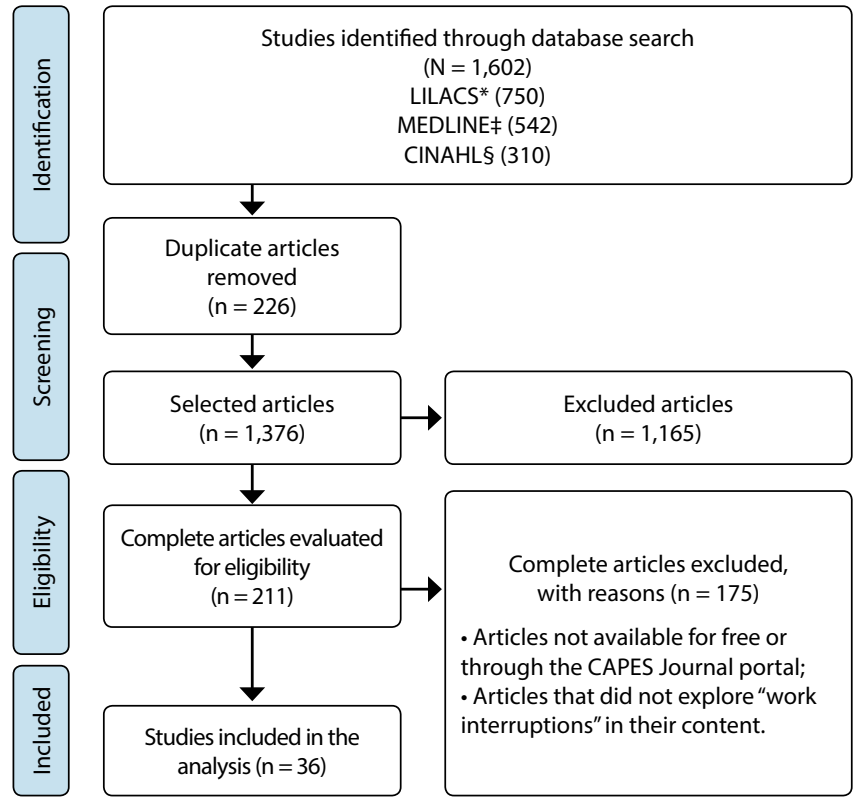

* LILACS - Latin American literature in Health Sciences; $¥$ MEDLINE - Medical Literature Analysis and Retrieval System Online (via PubMed); §CINAHL - Cumulative Index to Nursing and Allied health Literature.

Source: Adapted ${ }^{(20)}$.

Figure 1 - Flow chart of the method used in the search and selection of articles in databases, Divinópolis, Minas Gerais, Brazil, 2020

\section{Data analysis}

The study organized the data in relative and absolute frequency and presented it in a table for better understanding.

Researchers established a model case that exemplifies the appearance of the concept of "interruption in the work of nursing professionals", and an opposite case, which was an example of the non-occurrence of the concept to ratify the analyzed data. Both cases may arise from a real situation occurring daily, or from a fictitious circumstance, that is, created by the researcher, or from a condition described in the literature representing the use of the concept ${ }^{(18)}$. These steps contribute to the understanding of the attributes, antecedents, and consequences that best suit (or not) the concept.

\section{RESULTS}

The study selected 36 articles, which were from 14 nationalities, countries and with the highest number of publications coming from the United States of America (USA) $n=11$ ( $n=11 ; 30.5 \%)$ and Canada $n=5(n=5 ; 13.9 \%)$. The studies had publication between the years 2005 to 2019 . The years with the highest number of publications were 2017: $(n=6 ; 16.7 \%), 2018:(n=5 ; 13.9 \%)$, and 2019: $(n=6 ; 16.7 \%)$. The study organized the results as follows: identification of uses for the concept "interruption in the work of nursing professionals", determination of defining attributes, identification of antecedents and consequences, identification of the model case, and identification of the additional case (opposite case).

The definitions of the concept "interruption in the work of nursing professionals" were varied, that is, there was no consensus to define this phenomenon, as shown in Chart 1. 
Chart 1 - Expressions used by the selected studies to define interruptions, Divinópolis, Minas Gerais, Brazil, 2020

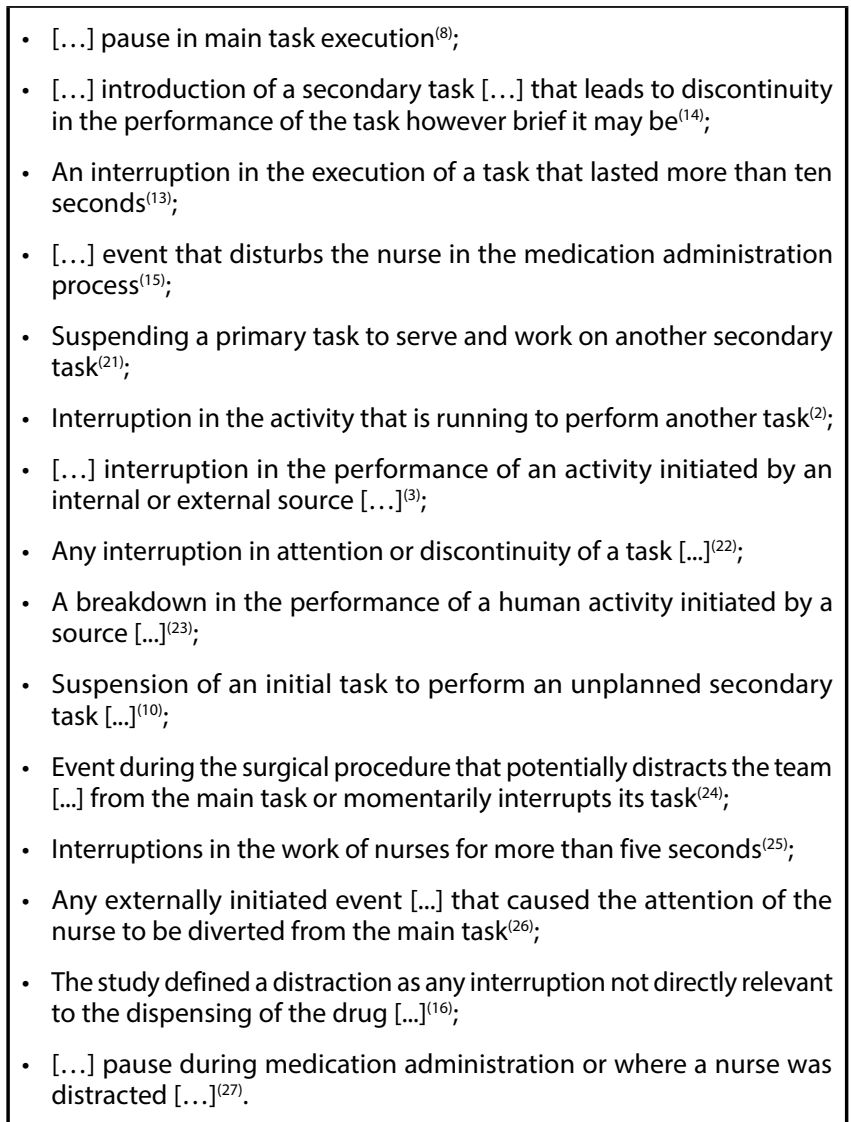

The study showed the results of work interruptions in several scenarios, such as operating room ${ }^{(3,28)}$, during the prescription, preparation, and administration of medications $s^{(1,13,15)}$, and in the transfers of the work shifts of health professionals ${ }^{(17,29)}$. Most (97.2\%) of the studies were conducted in hospital settings, such as Medical/Surgical Clinic ( $(=13)$, Adult $(N=7)$ and Pediatric $(n=3)$ Intensive Care Unit,
Pediatric Hospitalization Sector $(n=4)$, Urgency and Emergence ( $n$ $=5)$, Operation Room (OR) $(n=3)$; and, finally, $2.8 \%$ in the Primary Health Care $(\mathrm{PHC})(\mathrm{N}=1)$. Regarding the study participants, $77.4 \%$ of the articles focused on nursing professionals, $16,1 \%$, multidisciplinary team, and $6.5 \%$, medical professionals.

The attributes found in the literature regarding the concept "interruption in the work of nursing professionals" were the break in the performance of an activity ${ }^{(11-12,22,28-30)}$, pause ${ }^{(5,8,27,29,31)}$ or suspension in the execution of the task ${ }^{(5,10,21,30)}$, and unexpected intrusion into a task ${ }^{(5,11-12,27-29)}$.

Table 1 presents the absolute and relative frequencies of the antecedents and consequences of the concept under analysis. The study found that ambient noise is the most frequent background, followed by helping the patient. Medication errors (ME) and change of focus were the most frequent consequences in the studies.

The model case assists in the clarification and understanding of the concept's structure, so there is a need to understand its meaning and the context in which it occurs. Thus, the study describes the case model as follow: A student nurse of a PHC residency program, upon arrival at the Basic Health Unit (BHU), starts the scheduled demand care, such as individual visit aimed at the follow-up of the population. The nurse is assisting the appointments to monitor the growth and development of children. The first appointment of the day is that of a child of four months of age, in exclusive breastfeeding. After the Anamnesis, the nurse begins the physical examination. Suddenly, he interrupted by the nursing technician, who requests his presence in the dressing room for evaluation of a skin lesion. The nurse excuses himself with the child's mother and interrupts the care to perform this secondary task. The evaluation of skin lesions and prescription of coverings are specific activities of the nurse and necessary for the performance of the bandage by the nursing technician. After five minutes, the nurse returns to the medical office and realizes that he did not record the anthropometric measurements, having to perform the entire procedure again.

Table 1 - Frequency of the antecedents and consequences of the concept "interruption at work" $(\mathrm{n}=36)$, Divinópolis, Minas Gerais, Brazil, 2020

\begin{tabular}{|c|c|c|}
\hline Related factors & $\mathbf{F}^{*}$ & $\%^{+}$ \\
\hline \multicolumn{3}{|l|}{ Antecedents } \\
\hline Ambient noise $\mathrm{e}^{(1-2,4,6,8,10-11,13-14,21-29,32-35)}$ & 24 & 66.7 \\
\hline Meet patient requests (how to provide objects: cups, pillows) ${ }^{(1-2,5,10,14-16,21,25,27,29,32-34,36-38)}$ & 17 & 47.2 \\
\hline Answering phone calls $\mathrm{s}^{(3,6,8,13,16,21-22,27-29,32-36,38)}$ & 15 & 41.7 \\
\hline Lack of material ${ }^{(5,8-10,16,22,27-29,34,36,38-39)}$ & 13 & 36.1 \\
\hline Communication not related to the task to be performed $(3,8-10,14,21-22,24-25,27,32-33,35)$ & 13 & 36.1 \\
\hline Patient-related conversations ${ }^{(1,3,5-6,10,16,21-22,25,27-28,32,35)}$ & 13 & 36.1 \\
\hline Lack of patient information ${ }^{(5,8,10,15,21,32-33,35-36,38)}$ & 10 & 27.8 \\
\hline Lack of medication ${ }^{(10,16,21,23,32-33,36-37,39)}$ & 10 & 27.8 \\
\hline Lack of equipment ${ }^{(5,10,16,21-22,28-29,39)}$ & 8 & 22.2 \\
\hline Patient/family member provides or requests information ${ }^{(2,10-11,28,34-35,37-38)}$ & 8 & 22.2 \\
\hline Employees asking questions ${ }^{(10,15,21,28,34,38,40)}$ & 7 & 19.4 \\
\hline Equipment failure ${ }^{(1,8,15,21,24,35)}$ & 6 & 16.7 \\
\hline Conversation with patient/family ${ }^{(2,10,33-34)}$ & 4 & 11.1 \\
\hline Meet requests from medical professionals ${ }^{(5,10,36)}$ & 3 & 8.3 \\
\hline Wait for feedback (communication) from another professional(10,22) & 2 & 5.6 \\
\hline Receipt/exchange/control of materials ${ }^{(31-32)}$ & 2 & 5.6 \\
\hline Ask maintenance service ${ }^{(32,34)}$ & 2 & 5.6 \\
\hline Procedural planning failures ${ }^{(21,31)}$ & 2 & 5.6 \\
\hline Communication related to the unit or institution ${ }^{(22)}$ & 1 & 2.8 \\
\hline Absence of professional anesthesiologist ${ }^{(8)}$ & 1 & 2.8 \\
\hline Wait for exam result ${ }^{(8)}$ & 1 & 2.8 \\
\hline
\end{tabular}

To be continued 


\begin{tabular}{|c|c|c|}
\hline Related factors & $\mathbf{F}^{*}$ & $\%^{+}$ \\
\hline Contribution to education (guide student) ${ }^{(32)}$ & 1 & 2.8 \\
\hline Cleaning staff $(32)$ & 1 & 2.8 \\
\hline Admission of new patients ${ }^{(32)}$ & 1 & 2.8 \\
\hline Delivery of material to the laboratory ${ }^{(41)}$ & 1 & 2.8 \\
\hline Shift change/lunch time ${ }^{(21)}$ & 1 & 2.8 \\
\hline \multicolumn{3}{|l|}{ Consequences } \\
\hline Medication errors ${ }^{(2,5-6,10,12,16,21-22,25-28,31-34,36-37)}$ & 18 & 50.0 \\
\hline Change of focus ${ }^{(1,3,5-6,11-12,21,25,29-30,32-33)}$ & 13 & 36.1 \\
\hline Clinical malpractices ${ }^{(5-6,10-11,30,33,36,39)}$ & 8 & 22.2 \\
\hline Delay in care/treatment ${ }^{(5,10-12,27-29)}$ & 7 & 19.4 \\
\hline Increased frequency and severity of medication administration errors ${ }^{(6,9-10,25-26,33,36)}$ & 7 & 19.4 \\
\hline Longer task completion time ${ }^{(1,9,15,25,27,32)}$ & 6 & 16.7 \\
\hline Cognitive overload ${ }^{(3,5,25,33,35-36)}$ & 6 & 16.7 \\
\hline Abandonment of the main task $\mathrm{k}^{(1,4,21,27,38)}$ & 5 & 13.9 \\
\hline Procedural failures $s^{(3,10,33,36)}$ & 4 & 11.1 \\
\hline Adverse event ${ }^{(10,12,36)}$ & 3 & 8.3 \\
\hline Malpractices in the surgical procedure ${ }^{(8,24)}$ & 2 & 5.6 \\
\hline Poor quality service ${ }^{(40)}$ & 1 & 2.8 \\
\hline Delay in recognition and communication of patient changes ${ }^{(30)}$ & 1 & 2.8 \\
\hline Increased workload(6) & 1 & 2.8 \\
\hline Increased stress at work ${ }^{(1)}$ & 1 & 2.8 \\
\hline Dispensing errors ${ }^{(4)}$ & 1 & 2.8 \\
\hline Mistakes in prescribing/requesting exams ${ }^{(32)}$ & 1 & 2.8 \\
\hline Crushing of medicine without need ${ }^{(34)}$ & 1 & 2.8 \\
\hline Failed to complete or start tasks ${ }^{(21)}$ & 1 & 2.8 \\
\hline Failure to document/record information ${ }^{(10)}$ & 1 & 2.8 \\
\hline $\begin{array}{l}\text { Failure to check vital signs, blood glucose level, and neurological observation prior to medication } \\
\text { administration or when appropriate }^{(10)}\end{array}$ & 1 & 2.8 \\
\hline Provide critical and sensitive patient-related information ${ }^{(35)}$ & 1 & 2.8 \\
\hline Loss of critical information ${ }^{(21)}$ & 1 & 2.8 \\
\hline Patient fall ${ }^{(8)}$ & 1 & 2.8 \\
\hline Incomplete security checks ${ }^{(24)}$ & 1 & 2.8 \\
\hline
\end{tabular}

" - Absolute frequency; $\%^{+}$- Relative frequency.

One of the researchers experienced this case during his residency in nursing within the PHC. It is possible to identify the defining attributes of the concept, such as a break in the performance of the activity, pause or suspension of the service, and unexpected interference of a secondary demand.

The additional (opposite) case exemplifies the non-occurrence of the concept, as follows. A mother visits a BHU to vaccinate her four-month-old son. The nursing resident receives the mother and child in the vaccination room. The mother handed the Vaccine Book, and the nurse starts the registration of doses in the Information System of The National Immunization Program and the child's Vaccine Book. After registration, he washes his hands, prepare the immunobiological vaccine, administer it, and makes appropriate guidance on possible adverse reactions.

Thus, the conceptual analysis led to the structuring of a broader operational definition: a break in nursing work is"a break, regardless of time, in the performance of the main task with the transfer of the worker's concentration to a secondary task".

\section{DISCUSSION}

The definitions of the concept "interruption in the work of nursing professionals" diversified, sometimes inaccurate, and even incomprehensible for operationalization in research. It is evident the absence of consensus to define this event. The use of conflicting definitions may impair the comparison and results between distinct studies ${ }^{(41)}$ because it may not totally capture the interruption events or even cause mistakes in the classification of interrupts.
Some studies have used the term "distraction" as a synonym or characteristic of an interruption. These words, although similar, have distinct meanings ${ }^{(41)}$. In the event of distraction, there is no interruption of the task in progress, but only a deviation of the professional's attention. On interruption, the worker completely suspends the primary task in progress for the execution of a secondary task ${ }^{(8,41)}$.

The study also noted a divergence in the duration of the event to be considered an interruption ${ }^{(13-14)}$. No studies that measured the impact of the duration of an interruption on the procedures performed by professionals. However, there is evidence that any interruption negatively affects the memory and cognition of the professional due to the breakdown of attention in the task in progress ${ }^{(23)}$.

The study explored interruptions in various contexts of health care, mainly in the activity of preparation and administration of medicines ${ }^{(42)}$. It is one of the most complex and critical activities performed by nursing professionals. Studies report that interruptions in these procedures are the main contributing factor to the occurrence of medication errors (ME). In the United States, studies estimate that interruptions affect 1,3 million people per year. However, according to the World Health Organization (WHO), ME is a global problem. In 2017, the WHO launched the third Global Patient Safety Challenge to reduce the severe and avoidable harm related to drug use by $50 \%$ in five years ${ }^{(43)}$. Therefore, among other actions, prevention and mitigation of interruption events are mentioned as a powerful strategy to reduce errors during the preparation and administration of medication ${ }^{(7)}$.

The analysis of the articles evidenced the scarce approach to the theme "interruption in the work of nursing professionals" 
in PHC. This level of attention is the principal user access to the Health Care Network in Brazil and has a higher flow of patients receiving care than institutions at secondary and tertiary levels(34).

In general, it is also important to note that the articles used in this study refer only to nurses when they cite as "nursing professionals". The articles did not mention high school technician professionals, which does not reflect the Brazilian reality. There is a contingent of 2,471.153 nursing professionals in the country, of which $24.7 \%$ are undergraduate Nurses, $17.5 \%$ are Nursing assistants, and $57,8 \%$ are Nursing technicians ${ }^{(44)}$. That is, high school technician professionals correspond to more than $75 \%$ of Brazilian nursing, and they work directly in the care of patients, including the preparation and administration of medicines.

The attributes "pause", "suspension", "break", and "intrusion" identified by the conceptual analysis define the characteristics of the concept "interruption in the work of nursing professionals". Pause means "interruption of an action for some time" ${ }^{\prime(45)}$, whereas suspension is "the act of suspending, temporarily interrupting, suspended state"(46). Both definitions are similar, they set a time threshold assuming the task will resume at some point. A break is defined as an "act of breaking or break up, fracture"(47) and expresses the idea of complete disruption of activity. An intrusion is an unexpected event caused by external stimuli - e.g., by other professionals or by yourself - disrupting the workflow ${ }^{(27)}$.

Keeping attention and concentration on the performance of a particular task ensures the maintenance of cognitive resources during execution. Switching between tasks demands complex resources, affecting the performance and final result ${ }^{(48)}$. Thus, minimizing disruption events can contribute to safer patient care. Some strategies such as the use of colorful and unique vests for a given activity, the implementation of safe zones, environmental warnings, and professionals and patients education are used to reduce interruptions ${ }^{(9)}$.

The antecedents, that is, situations that occurred before the event of an interruption in the work of nursing professionals to the workplace, such as the noises of alarms, monitors, and telephones. Other situations referred to work activities, such as providing, consulting, or requesting information about patients, and communication between professionals and patients. Internal factors such as self-interruption, or external, such as environmental, human, or organizational factors can trigger interruptions ${ }^{(9)}$. It is essential to recognize them for defining strategies to minimize and manage unnecessary disruptions.

The consequences suggested linked to the medication system, compromised performance of professionals, and damage to patient safety. The study also observed abandonment of the main task and

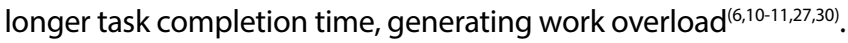

Most of the studies only identified and characterized the sources of interruptions. Although interruptions have great potential to cause errors, few studies related interruptions to consequences, based on primary studies in the field. Thus, there are limitations in the literature to relate interruptions to their consequences ${ }^{(12,36)}$.

Nevertheless, studies established a relationship between interruptions and increased stress at work ${ }^{(1)}$, delay in treatment ${ }^{(29)}$, loss of concentration ${ }^{(29)}$, and errors in assistance ${ }^{(10)}$. Interruptions affect cognitive ability, diverting the focus of information from the activity in progress due to an intrusion of a secondary task. Consequently, diverted attention predisposes to omissions and errors $^{(48)}$. Cognitive overload can affect the accuracy and performance of tasks, resulting in longer completion time, which can result in damage to the patient's treatment ${ }^{(48)}$.

The analysis emphasizes that there are situations in which interruptions are necessary for the context of nursing work. The work is not limited only to the execution of the task, but also to integrated nursing assistance to the patient. Thus, for example, to administer a drug, it is necessary to develop a process that covers the preparation, the collection of patient data, the communication with other health professionals to enable clinical reasoning in assessing the actual need for the prescribed drug ${ }^{(2)}$. Another situation is that interruptions may be inherent to the function performed. For example, the circulating nurse in an operating room tends to be interrupted at any time since it is his assignment to support the anesthetic-surgical intervention both in the supply of inputs and in the operation of equipment and monitors requested by the team ${ }^{(8)}$.

Considering the relevance of the theme "interruptions in the work of nursing professionals in health services", it is essential to establish an operational definition for this concept to contribute to the improvement of the clinical practice of professionals and scientific production. Understanding the concept contributes to the organization of the knowledge and enhances the operationalization of strategies to mitigate adverse events.

\section{Study limitations}

In general, the articles used in this study are international and refer only to nurses on how they use the term "nursing professionals" restricting it only to the class of "nurses". However, in Brazil, there is a large contingent of high school technician professionals that form the nursing team. Therefore, this denomination may transmit a wrong idea of the reality of nursing professionals in Brazil.

\section{Contributions to the fields of Nursing, Health, or Public Policy}

The results may identify both the characteristics associated with the interruption in the work of nursing professionals and the antecedents, attributes, and consequences, enabling the development of an operational definition. In addition, the standardization of the concept will contribute to the future creation of tools to identify and mitigate failures and errors resulting from interruptions in the work of nursing professionals and other areas of health, promoting improvements in the care provided to the patient in the various scenarios of health care.

Most of the publications exposed only the identification of the sources of interruption. Thus, the study suggests carrying out further research with longitudinal and/or experimental methodological designs that allow correlating variables and establishing (or not) a new operational definition of "work interruptions". In addition, in the Brazilian case, it recommends the inclusion of the different professional categories of nursing.

\section{FINAL CONSIDERATIONS}

The conceptual analysis of "interruption in the work of nursing professionals" identified and clarified the most frequent attributes, antecedents, and consequences in the literature. 
In the field of patient safety, studies addressed the concept, however, in a fragmented and sometimes incomprehensible way, with no defined consensus in the literature. The absence of a definition can hinder the proper identification of the phenomenon, and as well as the development of strategies to prevent interruptions in work and, thus, generate and possible harm to patients.

In the scenario of Primary Health Care, the studies on interruptions in the work of professionals are still early. It indicates the need for advances in the construction of knowledge and safer care practices at this stage of health care. In addition, there are few studies on interruptions in the work of high school technician professionals.
Considering that these professionals constitute the majority of the Brazilian nursing workforce and act directly in the care of patients, this gap in the literature becomes even more important.

Understanding the contributing factors of interruptions can help recognize the triggers that start unnecessary interruptions, subsidizing interventions to mitigate them.

The analysis of empirical data allowed establishing an operational definition of the concept, which can incorporated into discussions on patient safety both in the academic area and in health institutions and/or services, in addition to subsidizing the development of new research.

\section{REFERENCES}

1. Weigl M, Beck J, Wehler M, Schneider A. Workflow interruptions and stress at work: a mixed-methods study among physicians and nurses of a multidisciplinary emergency department. BMJ Open. 2017;7(12):e019074. https://doi.org/10.1136/bmjopen-2017-019074

2. Alteren J, Hermstad M, White J, Jordan S. Conflicting priorities: observation of medicine administration. J Clin Nurs. 2018;27(19-20):3613-21. https://doi.org/10.1111/jocn.14518

3. Forsyth KL, Hawthorne HJ, El-Sherif N, Varghese RS, Ernste VK, Koenig J, et al. Interruptions experienced by emergency nurses: implications for subjective and objective measures of workload. J Emerg Nurs. 2018;44(6):614-23. https://doi.org/10.1016/j.jen.2018.02.001

4. Drews FA, Markewitz BA, Stoddard GJ, Samore MH. Interruptions and delivery of care in the intensive care unit. Hum Factors. 2019;61(4):56476. https://doi.org/10.1177/0018720819838090

5. Monteiro C, Avelar AFM, Pedreira MLG. Interruptions of nurses' activities and patient safety: an integrative literature review. Rev Latino-Am Enfermagem. 2015;23(1):169-79. https://doi.org/10.1590/0104-1169.0251.2539

6. Zhao J, Zhang X, Lan Q, Wang W, Cai Y, Xie X, et al. Interruptions experienced by nurses during pediatric medication administration in China: an observational study. J Spec Pediatr Nurs. 2019;24(4):e12265. https://doi.org/10.1111/jspn.12265

7. Volpato RJ, Costa CSC, Moura AAM, Okido ACC, Silva Jr FJG, Zerbetto SR, et al. Educational intervention and positive expectancies about the alcohol use among students. Rev Eletronica Enferm. 2019;21:53621. https://doi.org/10.5216/ree.v21.53621

8. Ribeiro HCTC, Rodrigues TM, Teles SAF, Pereira RC, Silva LLT, Mata LRF. Distractions and interruptions in a surgical room: perception of nursing staff. Esc Anna Nery. 2018;22(4): e20180042. https://doi.org/10.1590/2177-9465-ean-2018-0042

9. Schroers G. Characteristics of interruptions during medication administration: an integrative review of direct observational studies. J Clin Nurs. 2018;27(19-20):3462-71. https://doi.org/10.1111/jocn.14587

10. Johnson M, Sanchez P, Langdon R, Manias E, Levett-Jones T, Weidemann G, et al. The impact of interruptions on medication errors in hospitals: an observational study of nurses. J Nurs Manag. 2017;25(7):498-507. https://doi.org/10.1111/jonm.12486

11. Rhudy LM, Johnson MR, Krecke CA, Keigley DS, Schnell SJ, Maxson PM, et al. Change-of-shift nursing handoff interruptions: implications for evidence-based practice. Worldviews Evid Based Nurs. 2019;16(5):362-70. https://doi.org/10.1111/wvn.12390

12. Bower R, Jackson C, Manning JC. Interruptions and medication administration in critical care. Nurs Crit Care. 2015;20(4):183-95. https://doi. org/10.1111/nicc.12185

13. Kosits LM, Jones K. Interruptions experienced by registered nurses working in the emergency department. J Emerg Nurs. 2011;37(1):3-8. https://doi.org/10.1016/j.jen.2009.12.024

14. Mamykina L, Carter EJ, Sheehan B, Hum RS, Twohig BC, Kaufman DR. Driven to distraction: the nature and apparent purpose of interruptions in critical care and implications for HIT. J Biomed Inform. 2017;69:43-54. https://doi.org/10.1016/j.jbi.2017.01.015

15. Elganzouri ES, Standish CA, Androwich I. Medication administration time study (mats): nursing staff performance of medication administration. J Nurs Adm. 2009;39(5):204-10. https://doi.org/10.1097/NNA.0b013e3181a23d6d

16. Kreckler S, Catchpole K, Bottomley M, Handa A, McCulloch P. Interruptions during drug rounds: an observational study. $\mathrm{Br} J \mathrm{Nurs}$. 2008;17(21):1326-30. https://doi.org/10.12968/bjon.2008.17.21.31732

17. Sousa LMM, Firmino CF, Carteiro DMH, Frade F, Marques JM, Antunes AV. Análise de conceito: conceitos, métodos e aplicações em enfermagem. Rev Investig Enfermagem [Internet]. 2018[cited 2020 Jan 28]:9-19. Available from: https://www.researchgate.net/ publication/330205622_ANALISE_DE_CONCEITO_CONCEITOS_METODOS_E_APLICACOES_EM_ENFERMAGEM

18. Walker LO, Avant KC. Strategies for theory construction in nursing. 6th ed. Boston: Person, Prentice Hall; 2019. p. 167-92.

19. Whittemore R, Knafl K. The integrative review: updated methodology. J Adv Nurs. 2005;52(5):546-53. https://doi.org/10.1111/j.1365-2648.2005.03621.x

20. Moher D, Liberati A, Tetzlaff J, Altman DG, PRISMA Group. Preferred reporting items for systematic reviews and meta-analyses: the PRISMA statement. Ann Intern Med. 2009;151(4):264-9. https://doi.org/10.7326/0003-4819-151-4-200908180-00135 
21. Göras C, Olin K, Unbeck M, Pukk-Härenstam K, Ehrenberg A, Tessma MK, et al. Tasks, multitasking and interruptions among the surgical team in an operating room: a prospective observational study. BMJ Open. 2019;9(5):e026410. https://doi.org/10.1136/bmjopen-2018-026410

22. Reed CC, Minnick AF, Dietrich MS. Nurses' responses to interruptions during medication tasks: a time and motion study. Int J Nurs Stud. 2018;82:113-20. https://doi.org/10.1016/j.jinurstu.2018.03.017

23. Huckels-Baumgart S, Niederberger M, Manser T, Meier CR, Meyer-Massetti C. A combined intervention to reduce interruptions during medication preparation and double-checking: a pilot-study evaluating the impact of staff training and safety vests. J Nurs Manag. 2017;25(7):539-48. https://doi.org/10.1111/jonm.12491

24. Antoniadis S, Passauer-Baierl S, Baschnegger $\mathrm{H}$, Weigl $\mathrm{M}$. Identification and interference of intraoperative distractions and interruptions in operating rooms. J Surg Res. 2014;188(1):21-9. https://doi.org/10.1016/j.jss.2013.12.002

25. Sørensen EE, Brahe L. Interruptions in clinical nursing practice. J Clin Nurs. 2014;23(9-10):1274-82. https://doi.org/10.1111/jocn.12329

26. Trbovich P, Prakash V, Stewart J, Trip K, Savage P. Interruptions during the delivery of high-risk medications. J Nurs Adm. 2010;40(5):211-8. https://doi.org/10.1097/NNA.0b013e3181da4047

27. Hall LM, Pedersen C, Hubley P, Ptack E, Hemingway A, Watson C, et al. Interruptions and pediatric patient safety. J Pediatr Nurs. 2010;25(3):167-75. https://doi.org/10.1016/j.pedn.2008.09.005

28. Hall LM, Pedersen C, Fairley L. Losing the moment: Understanding interruptions to nurses' work. J Nurs Adm. 2010;40(4):169-76. https://doi. org/10.1097/NNA.0b013e3181d41162

29. Hall LM, Ferguson-Paré M, Peter E, White D, Besner J, Chisholm A, et al. Going blank: factors contributing to interruptions to nurses' work and related outcomes. J Nurs Manag. 2010;18(8):1040-7. https://doi.org/10.1111/j.1365-2834.2010.01166.x

30. Spooner AJ, Corley A, Chaboyer W, Hammond NE, Fraser JF. Measurement of the frequency and source of interruptions occurring during bedside nursing handover in the intensive care unit: an observational study. Aust Crit Care. 2015;28(1):19-23. https://doi.org/10.1016/j.aucc.2014.04.002

31. Schutijser BCFM, Klopotowska JE, Jongerden IP, Spreeuwenberg PMM, De Bruijne MC, Wagner C. Interruptions during intravenous medication administration: a multicentre observational study. J Adv Nurs. 2019;75(3):555-62. https://doi.org/10.1111/jan.13880

32. Duruk N, Zencir G, Eşer I. Interruption of the medication preparation process and an examination of factors causing interruptions. J Nurs Manag. 2016;24(3):376-83. https://doi.org/10.1111/jonm.12331

33. Hayes C, Jackson D, Davidson PM, Power T. Medication errors in hospitals: a literature review of disruptions to nursing practice during medication administration. J Clin Nurs. 2015;24(21-22):3063-76. https://doi.org/10.1111/jocn.12944

34. Mahmood A, Chaudhury H, Gaumont A, Rust T. Long-term care physical environments: effect on medication errors. Int J Health Care Qual Assur. 2012;25(5):431-41. https://doi.org/10.1108/09526861211235928

35. Blocker RC, Heaton HA, Forsyth KL, Hawthorne HJ, El-Sherif N, Bellolio MF, et al. Physician, Interrupted: Workflow Interruptions and Patient Care in the Emergency Department. J Emerg Med. 2017;53(6):798-804. https://doi.org/10.1016/j.jemermed.2017.08.067

36. Salmen S. Interruptions in interventional radiology: a review of the literature. J Radiol Nurs. 2016;35(4):305-8. https://doi.org/10.1016/j. jradnu.2016.10.002

37. Özkan S, Kocaman G, Öztürk C. Interruptions during pediatric medication preparation and administration. J Pediatr Res. 2016;3(2):104-8. https://doi.org/10.4274/JPR.98704

38. Tomietto M, Sartor A, Mazzocoli E, Palese A. Paradoxical effects of a hospital-based, multi-intervention programme aimed at reducing medication round interruptions. J Nurs Manag. 2012;20(3):335-43. https://doi.org/10.1111/j.1365-2834.2012.01329.x

39. Brixey JJ, Robinson DJ, Tang Z, Johnson TR, Zhang J, Turley JP. Interruptions in workflow for RNs in a Level One Trauma Center. AMIA Annu Symp Proc [Internet]. 2005[cited 2020 Jan 29];2005:86-90. Available from: https://www.ncbi.nlm.nih.gov/pmc/articles/PMC1560877

40. Vasconcelos PF, Freitas CHA, Jorge MSB, Carvalho REF, Freire VECS, Araújo MFM, et al. Safety attributes in primary care: understanding the needs of patients, health professionals, and managers. Public Health. 2019;171:31-40. https://doi.org/10.1016/j.puhe.2019.03.021

41. D'Esmond LK. Distracted practice and patient safety: the healthcare team experience. Nurs Forum. 2017;52(3):149-64. https://doi. org/10.1111/nuf.12173

42. Dadlez NM, Azzarone G, Sinnett MJ, Resnick M, Ushay HM, Adelman JS, et al. Ordering interruptions in a tertiary care center: a prospective observational study. Hosp Pediatr. 2017;7(3):134-9. https://doi.org/10.1542/hpeds.2016-0127

43. World Health Organization (WHO). Medication without harm: WHO's third global patient safety challenge [Internet]. Geneva: WHO; 2017[cited 2021 Jun 14]. Available from: http://www.who.int/patientsafety/medication-safety/en/

44. Conselho Federal de Enfermagem (BR). Enfermagem em números [Internet]. Brasília, DF; 2021[cited 2021 Apr 22]. Available from: http:// www.cofen.gov.br/enfermagem-em-numeros

45. Dicionário Online de Português [Internet]. Porto: 7Graus. Pausa; 2019 [cited 2020 Feb 05]. . Available from: https://www.dicio.com.br/pausa

46. Dicionário Online de Português [Internet]. Porto: 7Graus; 2019 [cited 2020 Feb 05]. Suspensão. Available from: https://www.dicio.com.br/suspensao

47. Dicionário Online de Português [Internet]. Porto: 7Graus; 2019 [cited 2020 Feb 05]. Quebra. Available from: https://www.dicio.com.br/quebra

48. Couffe C, Michael GA. Failures due to interruptions or distractions: a review and a new framework. Am J Psychol. 2017;130(2):163-81. https:// doi.org/10.5406/amerjpsyc.130.2.0163 